\title{
環境実験都市オーロヴィル(南インド)の 成立及び発展の要因に関する研究
}

\author{
○加藤 大昌 $1 \cdot$ 近藤 隆二郎 2 \\ 1学生会員 滋賀県立大学大学院 環境科学研究科 環境計画学専攻 (厂522-8533 滋賀県彦根市八坂町 2500) \\ ${ }^{2}$ 正会員 工博 滋賀県立大学助教授 環境科学部 環境計画学科( $5522-8533$ 滋賀県彦根市八坂町 2500 )
}

\begin{abstract}
Aurovilleとは、1968年に、インド人哲学者のSri.Aurobindoとフランス人芸術家で彼の哲学を最も色濃く受け継い だ弟子であるミラ・アルフアッッサ(通称Mother)の哲学及び将来への展望に基づき、インド政府の保護・ユネスコの支 援のもと建設されたワールドコミユニティである。Auroville建設は砂漠と化した不毛の地を開拓することから始まり、 周囲の村や政府等との様々な衝突、Aurovilleの方針や運営を巡っての内部でのぶつかり合いを克服してきた経験に 基づき、規則や指導者を持たずに運営されている特殊なコミュニテイとしての社会システムを形成している。現地調 查を通じ、その環境社会システム成立の要因を解明し、今後のエココミュニティデザインの新しい方法についての提 案を行う。
\end{abstract}

Key Words : Auroville, India, philosophy, experimental city on environment, eco-community

\section{1.㻴境実駘都市の概念と研究の背量・目的}

\section{（1）環境実験都市とは}

本研究では、「環境実験都市」を、「そこに存在する環 境之調和・共生することを前提とし、その上で、集団及び 個人の目的達成に向けての行動に試行錯誤しながら実 験的に取り組み、1つの都市機能を備えた場所」と定義 する。これは、「人間の心の側面を重視した都市イメージ として提唱された'エコポリス’や公害防止・アメニティ形 成・自然保護・地球への負荷の削減を盛り込んだ環境庁 の’第2次環境計画”」"に実験的取り組みというプロセス を加えたものである。

\section{(2) 研究の背景及び目的}

現在、環境に配虑した都市像が様々な場所において 実験あるいは研究されつつあるが、まだその先行きは不 透明な状態となっている。そこで本研究では、実践性の 高い環境都市像のモデルとして、南インドに1968年より 建設されている環境実験都市オーロヴィル (Auroville: 以下AVと略記)に注目した(図-1)。

環境実験都市AVの環境社会システムの変遷をモデ ル化し、その成立及び発展の要因を解明することを試 み、その結果より、今後展開される環境都市構想やエコ コミュニティのデザインに必要な要素についての提言を 行うことを本研究の目的とする。



図-1 Auroville の位䐸

国内でAVに関する情報は、現段階では「Bio City」” に特集記事として揭載された程度であり非常に少ない。 (3) 研究の手法

主として現地調查および資料調査を行った。

(1)現地調查[1]:1998年 12月 24日～1999年 1月3日 / 近藤ノ視察およびヒアリング,資料収菒等

(2)現地調查[2]:1999年 9月15日～11月20日/加藤／ ヒアリング,インタビュー,アンケート,資料収集等

(3)資料調查[1]:AV内での出来事をまとめたAV内部週刊 
誌『Auroville News』”および対外向けにAVの活動内

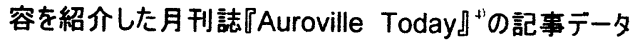
ベース化

(4)資料調査[2]:WebおよびAVにおいて収集した文献(パン フレット類含む)

(5)上記の膨大なデータを時代変遷および項目別に整理

(6)AVの環境社会システム(社会システム十環境システム) の変遷をモデル化

(7)AVの成立·発展の要因を解明

\section{AVの成立および発展の骤要}

\section{(1) AV創設者の哲学および設立意図}

インド人哲学者Sri.Aurobindoは「過去の人類が、『我 々(その時代の人間)が全ての中心である』と考えていた ことが、進化論的な視点の欠如であり、自分たちの寿命 を基淮とした時間軸の設定という間違いを引き起こして きた。人類は、自己中心的な存在から共生主義的な存 在へと進化しなければならない。」”説き、その哲学を 受け継いだ高弟であるフランス人芸術家ミラ・アルファッ サ(通称:Mother)は、その理想の実現のため、1968年に AVの建設に取り掛かった。当初、フランス人である Motherに対するSri Aurobindo Ashram (Sri.Aurobindoの弟子達が、Sri.Aurobindoの哲学/ヨ ガの体得のための場として、ポンディシェリーに建設した 道場: 以下Ashramと略記) や、建設予定地周辺の村か らの風当たりが非常に強く、その活動は困難を極めた。し かし彼女達が精力的に活動したことにより、その後インド 政府からの保護政策を受けるようになった。Motherは
1973年に亡くなるまで、彼女自身が創つたAVマスタープ ランに基づき、世界の変革・進歩に貢献するための理想 郷創にに献身した。

ここで、Sri.AurobindoやMotherの進化論的な哲学は 日常的に実践される「哲学」であり、「個人の幸福と共 に、地球全体の幸福を願い、活動するのだ」という高い意 識を持って、日々生活することこそが彼らの説く哲学( ガである。その実践の場としてつくられたのがAVであ り、AV憲章には、その理想が表われている。

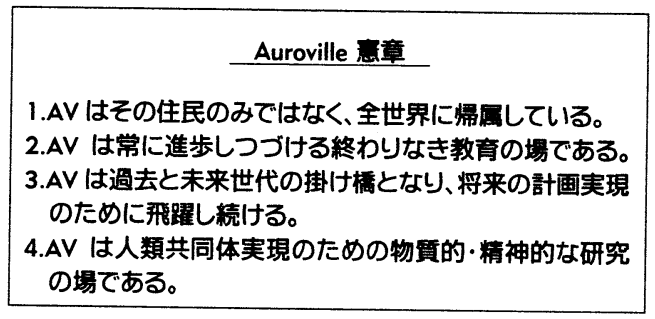

\section{（2）終わし無き前進の姿勢}

AV が掲げる理念やマスタープラン実現に向けての取 り組みは積極的に続いているが、「現在の AV はあなた が考える理想的な AV を 100\%とすると何\%完成してい るか」とう問いに対して「 50\%以上小という答えが AV 関係者からなかったことからも分かるように、まだまだ AV は未完成の段階である。何をもって完成と捉えるかは個 人の意識の問題であるが、「個人のアメニティの実現と 世界への貢献」ということは AV 完成の前提として述べ られている。また、「 AV は成長しつづける都市を目指し ているため完成はないよいう答えも多く聞かれ、オーロ

表-1 AVの歴史的経緯

\begin{tabular}{|c|c|c|c|}
\hline & $\begin{array}{l}\text { 第 1 段階 } \\
(1968 \text { 年〜 } 1970 \text { 年代 })\end{array}$ & \begin{tabular}{|l} 
第 2 段階 \\
$(1980$ 年代前半) \\
\end{tabular} & $\begin{array}{l}\text { 第 } 3 \text { 段陧 } \\
\text { (1980 年代後半～現在) } \\
\end{array}$ \\
\hline $\begin{array}{l}\text { 村との関 } \\
\text { 係 }\end{array}$ & $\begin{array}{l}\text { (1)土地の問題·西洋人への恐れから起こる } \\
\text { 村人の Auroville 拒否や闘争の発生 }\end{array}$ & $\begin{array}{l}\text { (1)拒否·闘争(一部和解) } \\
\text { (2) Auroville から村人への労働·㕍 } \\
\text { 用提供(ガードマン家政婦が主) }\end{array}$ & 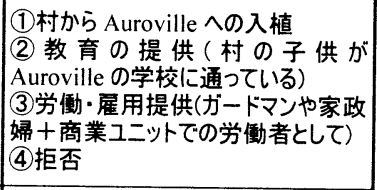 \\
\hline $\begin{array}{l}\text { Ashram } \\
\text { との関係 }\end{array}$ & $\begin{array}{l}\text { Ashram で修行を行っていたインド人がつくつ } \\
\text { た SAS(Sri.Aurobindo Society)が Auroville } \\
\text { の全権を握ろうとし、Mother のグループと衝 } \\
\text { 突が起こる }\end{array}$ & $\begin{array}{l}1980 \text { 年 } 11 \text { 月、インド政 府が } \\
\text { Auroville を保護し、周辺の村や } \\
\text { Ashram との闘争に終止符を打つた } \\
\text { めに「 Aurovile Emergency } \\
\text { Provision Act Jを議会において可決 } \\
\rightarrow \text { Ashram との闘争が終る }\end{array}$ & \\
\hline $\begin{array}{l}\text { インド政 } \\
\text { 府からの } \\
\text { 援助・支 } \\
\text { 援 }\end{array}$ & $\begin{array}{l}1969 \text { 年当時の現役首相であった Indira } \\
\text { Gandhi が Auroville の支持及び保護政策 } \\
\text { 立案を表明 }\end{array}$ & $\begin{array}{l}\text { 政府によって, Auroville 内外の掛 } \\
\text { け橋となる組織として「 Auroville， s } \\
\text { International Advisory Council 」が } \\
\text { 設置される }\end{array}$ & $\begin{array}{l}1988 \text { 年、インド政府は Auroville の } \\
\text { より良い運 党・発 展 のために. } \\
\text { 「Auroville Foundation Act 」を議 } \\
\text { 会において可決 }\end{array}$ \\
\hline $\begin{array}{l}\text { UNESC } \\
\text { O 他から } \\
\text { の援 助 } \\
\cdot \text { 支援 }\end{array}$ & $\begin{array}{l}\text { (1) } 1966,1968,1970 \text { 年の UNESCO 総会に } \\
\text { おいて、満場一致で Auroville 支援を決議 } \\
\text { (2) } 1969 \text { 年インドで第2位の資本金を誇る } \\
\text { 財閵 Tata Group 社長 Mr.J.R.D.Tataから } \\
\text { の継続的な全面的資金援助の申し入れを } \\
\text { 受けるーインフラ整備急進 }\end{array}$ & $\begin{array}{l}\text { 政府によって,Auroville 内外の掛 } \\
\text { け橋となる組織として「 Auroville } \\
\text { International Advisory Council 」が } \\
\text { 設置される }\end{array}$ & $\begin{array}{l}\text { (1) } 1992 \text { 年、UNESCO から } 25,000 \\
\text { ドルの寄付を受ける } \\
\text { (2) } 1997 \text { 年、エココミュニティとして、 } \\
\text { 「 the Blue Planet Prize 」受賞 }\end{array}$ \\
\hline
\end{tabular}


ヴィリアン(Aurovilian : 以下 AVian と略記)の向上心の 高さが伺えた。

\section{(3) 争い·援助}

AV の現在の社会の基盤になっている「無規則・無指 導者」というシステムができるまでの経緯を大きく 3 つの 年代に、また関係を(1) AV 内・周辺に点在する約 40 の 村、(2) Ashram 、(3)インド政府、(4) UNESCO を始めと する国際機関等、との関係という 4 つのカテゴリーに分 け整理する(表-1)。

インド政府から法的な保護を受けたことにより、村や他 の集団との闘争がなくなり、自らのアメ二ティの追及に終 始できるようになった。また、財政的には、インド財閥の理 解や UNESCO の支援などが効果的であったことが分 かる。

\section{(4) AVの将来像(図-2) \\ a) Key Hole Plan}

AV 中心部には、その象徵である Matrimandir が建 つている。1971 年以来建築工事は途切れることなく続い ている。今日、殠想の場である内部の部屋は完成された が、周囲の庭造り、および外部の骨組みの工事がいまだ 行われている。

AV の都市計画はこの Matrimandir を中心とし、半 径 $1.2 \mathrm{~km}$ の円の範囲に City Area、その周りの $1.2 \mathrm{~km}$ 幅に Green Belt つくり、また AV の所有する海岸にの びる幅 $1.2 \mathrm{~km}$ の放射状の土地を加え、「鍵穴 (Key Hole) 状の土地」を所有することを目指している。City Area は 4 つに区切られ、 International Zone , Educational Zone, Industrial Zone, Residential Zoneがおかれる(図-3)。International Zone では、世 界中の国の領事館の設置や各国の文化や伝統などを紹 介するパビリオンの設置を行い、留学生を積極的に受け

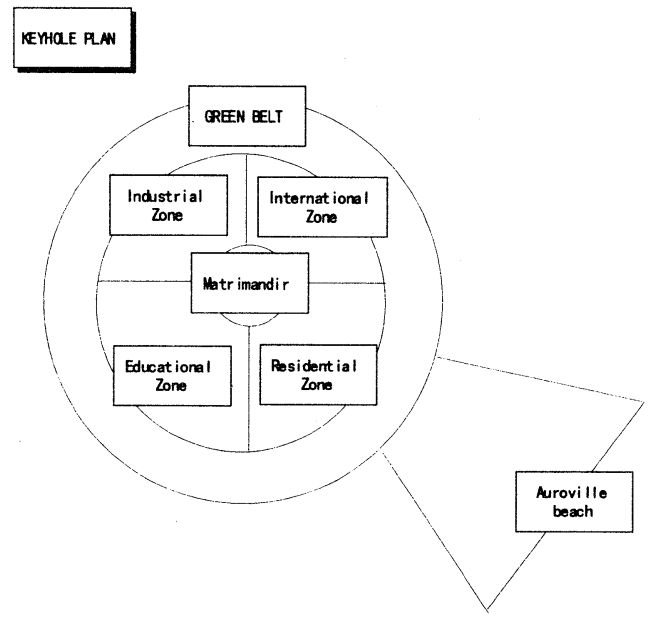

図-3 キーホールプランのゾーニング概念図

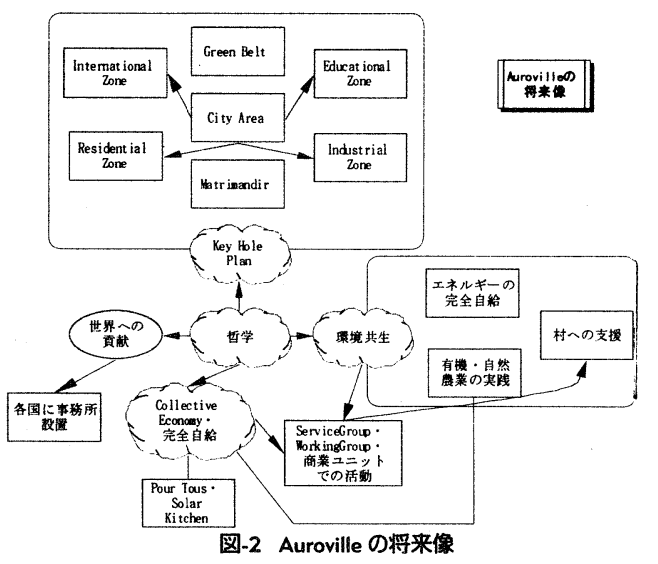

入れる。Educational Zone では、教育や様々な研究活 動が行われる。Industrial Zoneでは、世界に向けての 産業活動が行われ、AV 運営の資金調達を行う。 Residential Zone では、生活が行われる。おそらく現在 のコミュニティというものはなくなるであろう。また Green Belt と呼ばれる森林地帯には豊かな生態系が育まれる ことを目指す。

しかし現状では、AVは City Areaの75\%と Green Belt の 25\%しか管理下においておらず、周辺の村との 土地の売買についての交渉が課題となつている。

b) 自然との共生・エネルギー

今後の人口増加に対応するためには、水資源確保が 最大の課題となっている。利用可能な水資源を保全利 用する方法として、地上河川と地下水の流域の発展と 管理、荒地整備、漏出削減のための灌溉技術の改良、 屋根を利用した雨水・污水のリサイクル、散水システム のような身近な灌溉システムの普及、海水の淡水化技 術の開発等がプロジェクトとして挙げられる。

農業に関しては、AV の全農家及び周辺村の農家へ の自然農法・有機農法の普及・教育を徹底することが課 題亡なっている。

また、エネルギ一問題に関しては、今後消費量の増大 が危惧されるため、現在積極的に研究を進めている新工 ネルギーによる安定した電力供給をどこまで増大可能か が課題である。

c) Collective Economy·完全自給型社会

AV が目指している経済システムは、「 Collective Economy」である。商業活動により私産を増やすことは 問題ないという資本主義的な要素と、AV内での AVianの全活動には費用負担無しといった共産主義的 な要素を含んだ経済システムを目指している。自由競争 -個人資産の所有という商業ユニットの資本主義的要素 と富の共有・経済的平等思想といった共産主義的要素 を合わせた経済システムである。AVは貣困層の救済を 狙い、このような経済システムを導入した。これには商業 ユニットによる安定した利益獲得が必要となる。 


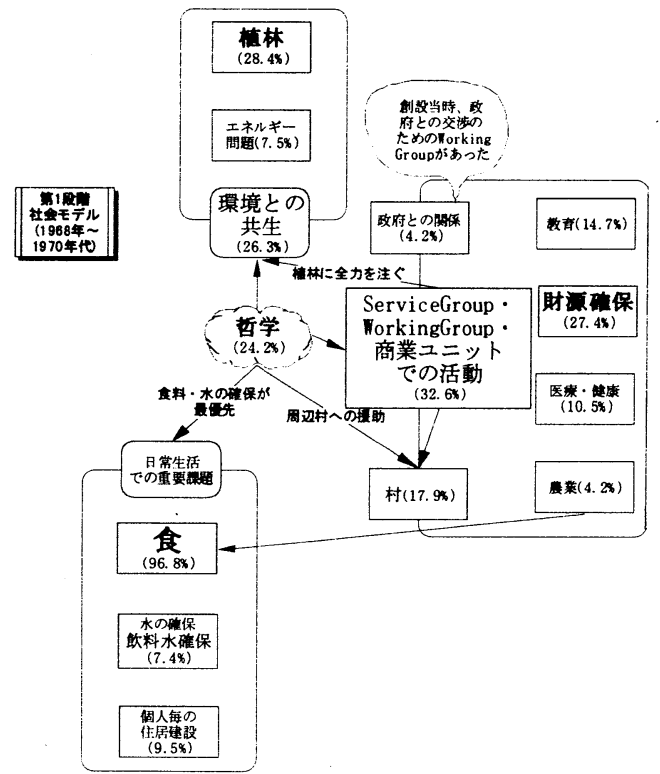

図-4 第1段陵(1968-1980)モデル図

また、住民生活に関わる全ての食料や物品を AV 内 で自給・処理する完全自給型・循環型社会を目指して いる。

\section{d) 人口と交通}

キーホールプランに基づけば、AV内の人口限界は 5 万人であると推計されている。現在の平均人口増加率 では、約 50 年後に達することになるが、実際は、AV 内 のインフラ整備や新住民用の New Comer House の数 の増加率を考えると、約 20 年後に人口 5 万人に達する 可能性が高いと考えられている。

その時、環境やエネルギーの問題以外で大きな問題 になると考えられているのが、教育と交通の問題である。 大人数による教育システムについての研究会が最近発 足したところで、まだ研究初期段階である。また交通に関 しては、City Area 内の移動手段として、AV内巡回低 公害バスの導入や自転車の普及、電気自動車が考えら れている。しかし実質的な研究は全く始まっておらず、こ れからの課題となっている。

\section{3.罢境社会システム分析}

\section{（1）分析の手法}

以上のように簡単な概要と現状の課題を示したが、以 下は、より詳細にその変遷について検討を加える。

$\mathrm{AV}$ の環境社会システムの変遷を明らかにするにあた り、『 Auroville News 』を、表-1 を基に、第 1 段階 (1968-1980)・第2段階(1981-1987)・第3段階 $(1988+)$ の 3段階に分け、(1)食 (pour tous, food, cook),(2)財政 (money, fund),(3)植林(tree, green, afforestation),(4)工

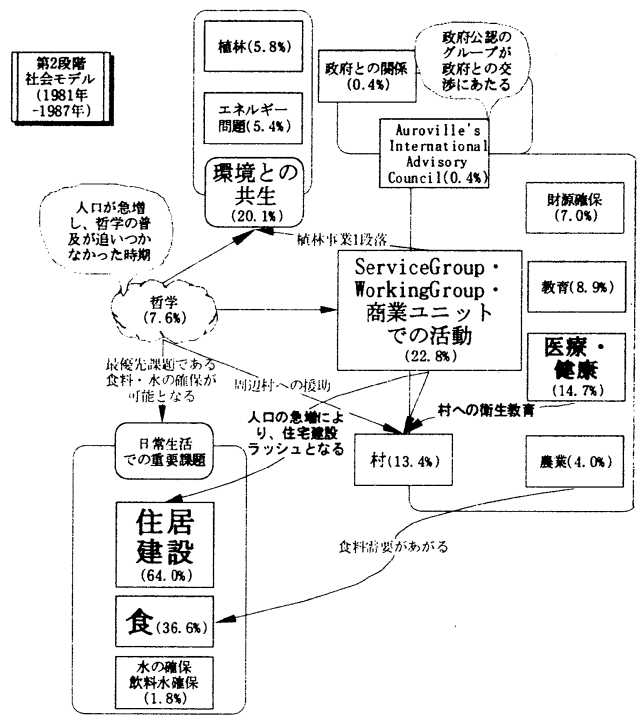

図-5 第2 段隌(1981-1987)モデル図

ネルギー (energy, alternative energy, solar),(5)村 (village, Tamil),(6)政府 (government),(7)哲学 (Mother, Sri.Aurobindo),(8) 教育 ( education, school),(9) 水 (water), (10)飲料水 (drinking water, water tank), (11)健康 (health),12活動 (Service Group, Working Group, work, ユニット),(13)住 ('community, house), (14)農 業 (agriculture, farm,crop, soil),(15) Collective Economy の 15 のキーワードの頻出割合 $(\%)$ (第 $\mathrm{n}$ 段階の頻出回 数/第 $\mathrm{n}$ 段階での Auroville News 発行回数)を求め た。その上で、AVの社会システムを「生活(私)」 $\lceil$ Service Group, Working Group, 商 業ユニットでの活 動等の公の場」「環境との共生」のカテゴリーに分け、各 カテゴリーのつながりおよびカテゴリー内で重要度の違 い(その段階で重要の高いもの= Auroville News で頻 出割合の高いものを大文字で示した)を明確にしてシス テム図化した。この図を基本として、各カテゴリーごとに 考察する。また、各種資料と共に、AVian 80 人へのヒ アリング調査の結果をも加味しながら考察を進める。

a)第 1 段階(1968-1980)/図-4:「生活」においては圧 倒的に「食」に関するキーワードが多く、創設期における 「食」の確保の難しさを伺える。また、創設期には大半の AVian が西洋人であったため、食文化の違いに苦しん だことも推察できる。「環境との共生」に関しては、水の 確保を含む「植林事業」に関する記事が頻出しており、 当時の「植林」への高い関心と取り組みが、荒れ果てた 砂漠地帯を森林地帯に変えていつたと考えられる。また 「財源の確保」では、インドの財閥 Tata グループからの 資金援助についての記事が目立つた。

b)第2段階(1981-1987)/図-5: 人口増加に伴い、「住宅 建設」や「医療」についての記事が目立つ。また、人口急 増により、AVの根本であるSri.Aurobindo・Motherの哲 


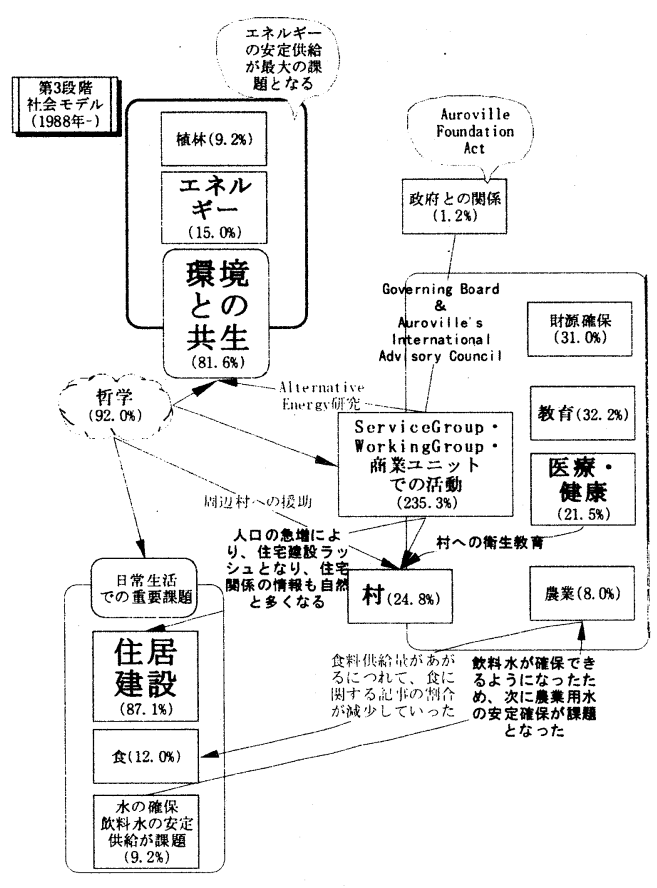

図 6 第 3 段階(1988-1999)モデル図

学についての教育が行き届かない状態となる。AVの理 想・理念の追求よりも、インフラ整備等のハード面での活 動が目立つ時期である。

c)第3段階(1988-1999)/図-6: 人口增加も落ち着き、 「村への支援」「環境との共生」といつたAVの本来の目 標達成に向けての活動が始まる。また、Sri.Aurobindo・ Motherの哲学、AVの理念についての記事がほぼ毎回 登場し、新入植者への教育も充実する。また、教育に関 する事業が急増する。

\section{(2) 社会システム}

\section{a) 社会意識}

なぜ AVに来たのかという問いに対して、AVianの多 くから「 Sri.Aurobindo,Mother の哲学に引かれて AV にやってきた」「AV の志に惹かれ AV にやってきた」と いう答えが返ってきた。AV の発展はこの哲学・理念の 共有化に基づいていると言えよう。今後人口が増加する に当たっても、この意味共有化がますます必要になり、入 植者に対する AV 理念についての教育体制整備が急が れる。

また、規則やルールのないコミュニティであるからこそ 「嘘をつかない、信頼関係の大切さの理解」が最も大事 であるという話も多く聞くことができた。AV は元々「世界 への貢献」とともに「個人のアメニティの実現」を目指して いる。そのため、 AV 創設期から Sri.Aurobindo や Mother の哲学に惹かれるよりも自己実現のために AV の住人になった人々も多いようだ。そのため、規則や指導
者を持たない社会システムが定着し、発展していつたの だ。

\section{b) コミュニティ}

AV の人口が正確に把握できるのは 1984 年以降で ある。1984 年末時点での人口は 538 人であった。それ 以降は平均約 7\%増加し、1998 年末時点で 1480 人と なり、現在は 1500 人を超えている。AVianになるために は、 1 年間の準備期間として New Comer House(New Comer House は AVを離れた·死亡した人々が使っていた家 を利用している)で暮らさなければならない。その結果、本 人の意思で移住について決定する。New Comer House の数に限りがあるため、移入者の数が急増するこ とはない。

また、コミュニティは現在80ある。各コミュニティは1〜 数十人で構成されている。この居住者数のばらつきは、 公共施設やshop等がある、生活に便利な場所に近いコ ミュニティに人が集まり、逆に、森の中など自分が最も落 ち着く場所に、俗世的に暮らす場合は単独のコミュニテ イとなることに起因している。また、New Comer House を 出てAVianになっても、自分で家を建てる資金のない人 は、AVを離れた・死亡した人々が使っていた家を利用で きるシステム(Housing Serviceというサービスグループに事前 に登録しておく。またこれはCollective Economy実現のための 手段でもある)になつている。

また、個人で家政婦や庭師を雇用する人たちもいる が、基本的にはコミュニティ単位で雇用し、曜日ごとにコ ミュニティ内の各家庭を回るシステムを採用している。コ ミュニティ内の居住者・商業ユニットは一定のお金を出 し、コミュニティとしてのロ座を持ち、共同雇用している 家政婦や庭師に給与を支払う。また、コミュニティがゲス トハウスを経営し、コミュニティとしての収益をあげている 場合もある。その他、地下水の汲み上げ、そのポンプの 維持·管理はコミュニティごとに行われている。

以上より、コミュニティ内の住人の結びつきは非常に 強いが、コミュニティ同士の関わりは弱く、AV全体での 祭礼などは全くない。

\section{c) Pour Tous · Solar Kitchen}

Pour Tous は、創設直後につくられた Auroville Management Found が経営する生活用品・食料品全 般がそろう shop であり、Auroville Management Found の資金調達源となっていると共に、住民の生活の利便性 向上に役立っている。AVは Collective Economy実現 のための手段の 1 つにキャッシュレス社会を揭げている。 そのためにつくられたのが Pour Tous であり、コンピュー ターによる個人の登録財産の管理により、住民カ一ド提 示と領収書へのサインのみで購買が可能である。また最 近では、AV 内の商業ユニットの会計の大半がこのシス テムを取り入れている。現在では、このようなシステム自 体をPour Tousと呼んでいる。しかし、このシステムは、 防犯上の問題点はほとんど解決されていない。 


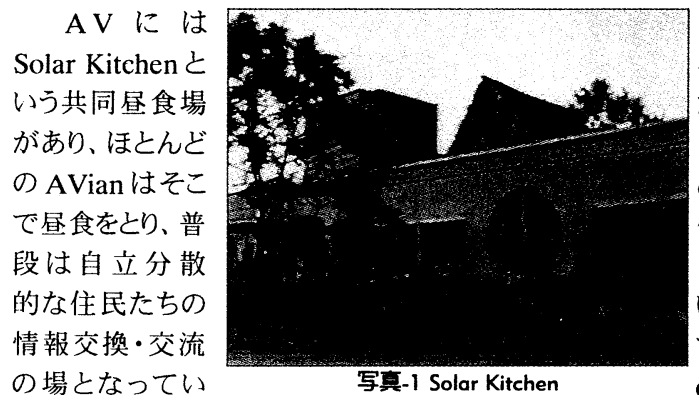

の場となってい

与異-1 Solar Kitchen

る。地理的・健康上の理由により Solar Kitchenに行け ない人に対しては宅配サービスを行っている。AVian は 毎月 350 ルピー、ゲストは 1 日 35 ルピーを支払い、その 収益によって仕入れ・施設管理・人件費を賄っている。

$\mathrm{AV}$ は元々共同生活コミュニティであったため、現在も 昼食・夕食の調理を順番制にして、住人全員でとってい るコミュニティもあるが、これはかなり少数である。ヒアリン グでは Aspiration というコミュニティだけであった。

d) Service Group,Working Group,商 業ユニット

(図-4,5,6でのキーワード)

AV内外の公益のために活動するのが、 Service Group, Working Groupであり、AV創設時から多種多 様なGroupが生まれてきた。資金は基本的に、Financial Serviceが管理するAuroville Management Foundから 受けることができる。Group運営のために、活動収益をあ げる場合もある。現在登録されているService Group, Working Groupの数は約40にのぼり、水道工事,住宅建 設,旅行代理,生活品販売など生活に密着したグループ から環境,芸術,文化などについての研究・活動を行うグ ループまで様々なものがある。

$\mathrm{AV}$ に拀いて収益目的の商業・産業的なユニットがで きたのは最近であるが、細工製品等に関しては国内出 荷のみならず輸出も行えるほどの成功を収めている。現 在AVの中には、大小約100の商業ユニットがあり、AVに 管理されている。その内容は多様であり、細工製品で言 えば、既製服,ろうそくや線香,陶器,紙製ランプ,木製品, 革製品,編物,石彫刻等が挙げられる。他には、林業,印 刷やグラフィックスデザイン,食品加工,電気製品,コンピュ 一ターのハード・ソフトの開発,発電用の風車の製造,住宅 ・公共施設の設計や建設等,家具製造,が挙げられる。

これら商業ユニットを発展させることにより、AV は完 全自給自足型社会を目指している。商業ユニットは、そ の基本的なサービスや経営を維持することにより、コミュ ニティの運営の資金をつくつている。また、商業ユニット は周辺の村の村人たちが生活水準を上げ、高度な技術 を得られるように職業訓練を行い、雇用を創出している。 現在 3000 人以上の村人が $\mathrm{AV}$ 内で働いている。その 人たちの大半は AVで職業訓練された人たちである。仕 事の内容は洗濯,農業,ガーデニング,運転,家事,会計,教 育,販売,監督,開業と維持管理(現在周辺の村から $\mathrm{AV}$ に
入植したインド人の中で 6 人が起業し、自らの商業ユニットを 持ち経営を行っている), 手工業, 刺紼,コンピューター操作に まで及んでいる。

また、引退による生きがいの嗫失というものを減らすた めに、Service Group, Working Group之共に、高齢労 働者を支援する体制をとつている。

皆が、「好きなこと・やりたかったことに従事している」と いう実感から活き活きと研究・活動・ビジネス等に従事し ていると言えよう。

\section{e) 教育}

$\mathrm{AV}$ 憲章は終わりなき教育の場としての AV を語って いる(図-3,4,5,6 AV 創設理念の1つで、Motherがその哲学 の中で、教育の重要性を説いている)。その影響か「生涯学 習の場としての Auroville」という需囲気が非常に強いよ うに感じられた。なお、創設期より学校はあった。

現在 AV には保育所,幼稚園,小学校,中学校がそれ ぞれ2力所、そして高校が1力所あり、 AV 周辺の村の子 供たちのための定時制学校が 15 ケ所以上ある(図-6 AV の現在の活動の中で教育事業は最重要課題の1つとなってい る)。13の AV 周辺の村から通っている子供と AVianの 子供と、合わせて 1000 人以上の子供が AV の教育プ ログラムを受けている。AV 内の学校では、芸術・体育・ 語学が基礎科目、その他は選択科目として各自がプロ グラムを組むシステムをとっている。子供の頃から自由を 第 1 に考えるという AVの方針が現れている。

AV では、「教育は、子供の潜在能力をできる限り最 大に高めるために努力している。」と、教育に関するリ一 フレットに書かれているように、自由選択システム、段階 コース制が取り入れられていて、生徒達が自分自身のプ ログラムを作れるようにしている。スポーツや体育はバラ ンスの取れた健康な子供を育てるためにかなり重視され ている。芸術教育は、芸術的才能と美的センスを養うた め、教育システムの本質的な部分となっている。

AVの教育は、SAIIER(Sri.Aurobindo International Institute of Educational Research)に管 理されている。SAIIER は 1984 年に子供と大人、雨方 の為に AVにある多くの資源活用に焦点を置いて創設さ れた組織である。AV の教育活動に関する研究報告書 が定期的に出版されており、最近では、人生の目的獲 得、教師生徒の良い関係の創造といつた課題への新しい アプローチが始められている。

また、生涯学習が活発に行われており、スポーツ・体 カづくり,美術,音楽,語学,哲学,コンピューターなどのアフ タースクールが非常に数多く、頻繁に行われている。

$\mathrm{AV}$ 創設当初より、周辺村の子供たちは $\mathrm{AV}$ より特別 な保護を受けてきた。村の子供たちのための学校,栄養 プログラム,運動場,スポーツプログラムは初期段階より行 われていた活動である。またあるケースでは、村の子供た ちが「養子」になり、単独またはグループで、AV 内で育 てられた結果、現在のコミュニティのメンバーとして AV 
に住む村生まれの若い男女が何人もいる。彼らは教育を 受け、職に就くことができている。また、 AV 及び周辺の 村の大人を対象に、趣味の学校や職業訓練学校(語学 やコンピューター等)も開かれている。

\section{f) 財政}

$\mathrm{AV}$ を建設・運営するための最初の資金は Ashramに いたインド人富豪によって寄付された。その後、AVの実 権をめぐって Ashram と衝突が起こつたため資金援助が 打ち切られ、窮地に立たされるが、インド財閥 Tata Group 社長 Mr.J.R.D.Tata からの継続的な全面的資 金援助やインド政府からの資金援助を受けることが可能 となり、窎地を脱する(図-4:財源確保)。この頃の支出の 多くは AV 内のインフラ整備や敷地拡大等に費やされて いた。

現在、AV の収支·財政管理を行うのは、Economy Groupの中の Financial Service という Working Group である。現在の収入に関しては以下のようになっている。

(1)Grants \& Donations (18歳以上 1650ルピー/月, 18 歳未満500ルピーノ月)

(2)Commercial Activities (可能な限り、毎月寄付という 形で収める)

(3)Sri.Aurobindo International Institute (Sri.Aurobindo の哲学を研究し、広めるインドのNGOで、Aurovilleに対 して文化·教育面への寄付を行っている。

(4)NGO（世界中のNGOから、Auroville及び周辺村の開 発·研究のためへの寄付)

(5)Indian Government (Auroville及び周辺村の開発・研 究のためへの寄付)

(6)その他(Guestの滞在料(18歳以上 50ルピーノ日, 12歳 以上18歳未満 25 ルピーノ日)や世界中の個人的なAu rovilleの支持者からの寄付)

支出目的は以下のようになっている(図-6:第3段階で

の頻出キーワードとほぼ同様)。

(1)インフラストラクチャーの整備

(2)教育・文化活動

(3)周辺村の開発

(4)Working GroupやService Group への援助（公共施 設運営や環境に関する研究等多種多様)

基本的には私有財産を持たず、共有財産ということに なっているが、実際には、AV移住時に持ち込んだ財産 やAVに入ってから得た収入をAV内にあるIndian State Bankに貯蓄して私有財産を保有している。こような所 にもAVの規制や規則がないという姿勢が現れている。

\section{（3）環境システム}

\section{a) 創設期における環境との閭い}

(1)植林(図-4 AV 初期段階での最重要環境問題)

Auroville は荒地の開墾や森林再生の成功のため、 国家的かつ国際的な絶賛を浴びるようになった。2500 エーカー以上もの、ほとんど不毛で、死んでいた土地が

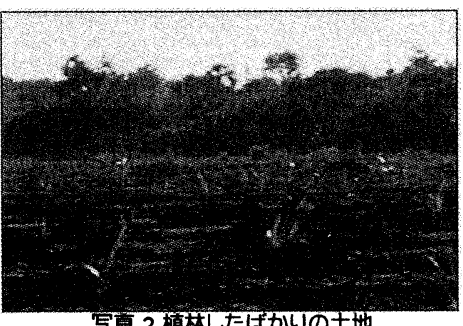

青々とした緑地 帯となつた。これ はAVian 84 人 を対象に環境 意識についてヒ アリング調査を 行った結果から も分かる。”

$\mathrm{AV}$ の景観 色イメージは、緑(森林)が $80 \%$ 、茶(土)が $13 \%$ 、赤(赤 土)が 4\%となり、普段の生活に森林が深く関わっている ことがわかった。これは Auroville 創設の頃から熱心に取 り組まれてきた「植林事業の成果」であると捉えられる。 また、赤というのは $\mathrm{AV}$ 敷地の中でも少し残っている赤 土のことを指している。

AV ではいたる所に bunds をつくることにより、雨季に 降る水を有効利用し、200 万本以上の森林、生垣、果 物、そして燃料用の木を様々な種類で試行錯誤しながら 植林した。

AGRC(Auroville Green Resource Center) は地下 水の利用、荒地の開墾、植林に関する調査を行い、イン ドや外国からの生徒に養成課程を提供している。AGRC は積極的に国際交換ネットワークにも参加している。

また、The Auroville Center for Ecological Land Use and Rural Developmentを目的とした Working Group である Palmyra は、村の 2500 エーカ一もの広さ の土地に 120 万本以上もの木を植林し、土と水の保護 と森林再生活動を 8 年以上も続けている。Palmyra は また、村の農家の人々、NGO、生態学あるいは持続可 能な土地利用に関わる政府の幹部に、訓練プログラムも 提供している。

\section{(2)水の確保}

最初は、揚水用のポンプや装置の修理や調整に追わ れる毎日であった。AVでは、約 60M 掘り続けなければ 水を汲み上げることができなかった。また、飲み水として として適した水質にするための試行錯誤を繰り返してい った。また、集住形態から単独居住までばらばらなため に、揚水装置の設置範囲や、AV に隣接している村の 水利用との関係などが問題となった。

$\mathrm{AV}$ の住人たちは各家に水(雨水収集)多クを設置し ていたが、修理や手入れの仕方を知っているわけでもな く、また雨季以外は雨が降らなかったので、タンクも古く なり、壊れていく始末だった。

プロジェクトとしては、第 1 に、乾期は雨水を期待でき ないため、地下水の揚水装置の普及拡大であった。第 2 に、地下水の汲み上げにおいて、 1 度に大量の水を汲み 上げると(庭への水遣りなど)、かなりの間水を汲み上げる ことができなくなることが問題となっていたため、常時汲 み上げを行い、その水を雨水と共にリザーブしておく装 置を取り付けることであった。プロジェク外実施にあたって 
直面したのは活動資金の確保と人々の問題であつた。前 者は、Auroville Management Foundからの援助により 解決した。最初、人々はプロジェクトチームに不信感を持 ち、頼ろうとしなかったが、根切丁寧な説明と、修理・改 良を繰り返していくうちに順調に水が確保できるようにな ると、人々はプロジェクトチームを受け入れ、信用してくれ るようになつた。

\section{b) 謤境問題への取り組みの変运}

1968 年、 AV が創設されたとき、土地は荒れ果て、 少しのプラム、マンゴーやバンヤンノキのみが広くて大き なレッドアースに点在していた。これは 200 年間に及ぶ森 林伐採、粗悪な土地管理や過放牧による破壊の結果で あつた。

しかしながら、最初の入植者たちは不毛の地の森林再 生に着手していった。穴が掘られ、大量の堆肥が近くの 村から集められ、苗木を育てるための水を $3 \mathrm{~km}$ 先から毎 日運ばなければならなかつた。森林再生の初期段階にお いて、干ばつに耐えられる丈夫な植物が植えられ、とげ の多い植物の柵が若木を牛や馬から守るためにつくられ た。現在では 300 種類以上の樹木が植えられている(図 $-2,3,4$ 植林事業の継続)。

同時に、土地再生のための治水保全プログラムにも着 手した。これは雨水を貯め、流れ出すのを調節するため に何 $\mathrm{km}$ もの” bunds 'を掘ることを行った。防水ダムが 流れ出る水をせきとめるためにつくられ、今ある集水池が 土地の蓄水量を増加させるためにつくられた。

土地再生が何年も継続されるとともに、木が成長し、 土地が回復してきたために、多くの種類の鳥や動物が戻 り、生態系としては、砂漠から小さな森へと変化した。現 在では鳥や動物 (94 種以上もの鳥、ジャコウネコ、オオト カゲ、ハイエナ、マングースといった危険にさらされている 小動物などが(る) を AV 内の森に放す事業を行って いる。森は増加し、200 万本もの木や多くの低木、つる、 植物が今 AVの約 $20 \mathrm{~km}^{2}$ を覆つている。

\section{c) 現在の環境䧓題と対処}

\section{(1)有機蕽業}

(図-4,5,6 : 農業の重要性の高まり、「食」への直結)

有機農業の導入により、殺虫剂や化学肥料が排除さ れ、 agro-foresty 技術の忘用が積極的に推し進められ ている。周囲の村では、農家と共に、化学肥料や DDT のような有害な殺虫剤を使った土地を元に戻すための努 力がされている。しかし、それらの化学物質は今でも容 易に入手できるため、村人への有機農業についての教 育、生物分解性のある殺虫剤代替物の研究が最重要 課題となっている。

有機農業への移行理由の 1 つは健康への関心であ る。もう1つは、有機農業により土の保水能力を維持し、 水使用量を減らすことができることである。また、保水能 力が高い土地には水をどんどん撒く必要がなく、バクテリ アの活動を妨げないことにつながり、化学肥料や殺虫剤
の不使用とあわせて、土が豊かになっていくのである。

また、先述の環境意識調査で「 Auroville の環境に対 して今後あなたは何ができるか」という問いに関して、有 機農業の実践,有機野菜製品の購入,生ごみの自宅(コミ ユニティ)でのコンポスト化,ごみの減量,ごみ拾い,ごみの 分別,節水・節電の徹底,生活排水の自己処理,オートバ イから自転車への乗り換え,学校での環境教育,村人への 環境教育,自宅周辺への植林,殺虫剂の不使用などが主 に挙げられた。

農業排水の水質改善に関しては、化学肥料や殺虫剤 の不使用により污染を軽減する一般的なメ夕ボリックカ ルチャーに対して、別のアプローチとしてアクア・アグリカ ルチャー(fish farming)が挙げられる。AVでの農業は 1 年のうち 6 ケ月間(乾期)はほとんど貯水のみで行わなけ ればならない。その貯水池で魚を飼うのである。魚は食 料になるため、村でもこの貯水を大切にする。つまり、村 人に対して、最初に本能的な部分 (魚という食料の確保) に訴えかけ、次に社会的に認めさせることにより貯水池の 保護を行うのである。

また Auroville Farming Groupは、有機作物に特別 な市場ルートを開拓することにより、有機農業を支援して いる。最近やっと、有機農業で育てられたフルーツ、野 菜、キビ、その穀物でつくられた新しい食物を開発し、そ れらを市場化した。

\section{(2) Renewable Energy・ごみ問題}

(図-6:エネルギ一問題の重要性が急浮上)

$\mathrm{AV}$ では、持続可能な新エネルギ一資源について実 験を行っている。AVで利用されている持続可能な新工 ネルギーは太陽、風、バイオマスである。現在実際に、こ れらの新エネルギーは $1200 \mathrm{~V}$ 以上、電気と水の供給の ために利用されている。30 基の風車が揚水ポンプの電 源として使われ、バイオガスシステムはメタンガスや有機 肥料を作り出すために動物の死咳や生ごみを化学的に 処理している。今日、AV はインドで持続可能なエネル ギ一資源についての国の実験施設となつている。

1984 年にインド政府に公認された環境問題に関する研 究所であるCSR(Center for Scientific Research) は AV の睘境問題に関する活動の中心を担っている。研究 内容は、第 1 に solar energy に関して： solar photovoltaic, photovoltaic pumps, photovoltaic lighting system, solar power plant, solar thermal flat plate collectors, solar thermal concentrators $の$ 開発。 第 2 にind energy 関して： windmill, wind generators の開発。第 3 にbiomass energy の研究であ る。また、AVで用いられている環境配慮技術を、 NGO, 政府幹部,学生に対して「Awareness Workshop towards a Sustainable Future」を主催し広めている。

先述の環境意識調查から以下のようなことも分かっ た。AVの社会の中で最優先的に取り組まなければなら ない一般的な課題としては、エネルギ一関係の問題 
$30 \%$ 、ごみ問題 $26 \%$ 、教育(村人の教育を含む) $23 \%$ 、 村からの土地の買収 $12 \%$ 、有機農業 $4 \%$ となり、エネル ギ一問題に対する意識の高さが司えた。

また、ここでのごみ問題というのは AV の敷地の中に 点在する村から出るごみのことであり、草地が一面ごみ で埋め尽くされている場所もあった。AVではごみ収集・ 処理についてのインフラ・技術が全くと言つていいほど整 備・発展していないという印象を受けた。ごみの分別に取 り組んでいるコミュニティもごく少数あったが、結局は一 緒にされポンディシエリ一の買い取り業者に引き渡され る。プラスティック製品を大量に含んだこの有害なごみは ポンディシェリー周辺の農家に肥料として売られるという ことであった。今後 AV はこの問題解決に取り組んでいく 必要があると考える。また、10 代・20 代の世代は $80 \%$ がエネルギー関係の問題、ごみ問題を挙げており、弱年 層の環境問題に対する興味の高さが伺えた。

また、日常生活の中で環境に配慮していることについ ては、節電 $52 \%$ 、節水 $36 \%$ 、有機農業実践農家からの 野菜購入 $10 \%$ 、自宅へのソーラーパネル $2 \%$ の取付け となった。買い物時の容器包装の減量に向けての買い物 袋・容器の持参というのは当然のこととなっており、誰も が当然のこととして実践している。

今後 AV の中で課題となる環境問題は何かということ については、エネルギ一使用量の増大 $56 \%$ 、交通 $18 \%$ 、水の確保 $14 \%$ 、森林内の生態系の保護 $12 \%$ とい うことが挙げられた。これらの問題は、毎年その人口を増 やしていっている Auroville にとつては早急に対処しなけ ればならない問題となってきている。交通問題とは近年 自家用車・オートバイの使用が急増してきており、大気 污染が問題となってきていることを指している。

\section{AVの特徴および得られた知見}

\section{(1)AVの特徴}

本研究より得られた AV の特徵を下記にまとめる。

(1)暂学·思想・傮乗の共有化…S Sri Aurobindo および Mother の思想が住民に共有化されており、新移住者に 対する 1 年間の体験プログラム内でも浸透が試みられて いる。AV は宗教なのかという論争もあるが、住民にとつ ては宗教では無いと考えている。AV の思想は、確かに 細かな教義というよりは、考え方のようなものを説いてい るものが多く、むしろ信条と呼んだ方が良いと思われる。 (2)ワールト・コミュニティ…記信条の共有化とも関連す るが、インドやフランスを強調することなく、国や民族を越 えた集団によって構成されている。各民族性を尊重しな がらも、そこにとらわれることなく、新たない小に成長しよ うという哲学が基層にある。

(3)非管理システム…AV の特徴を最も現しているもので あり、基本的にはルールや規則は明文化されては存在し ていない。これは、6,70 年代のヒッピー文化を受け継い
でいるものとも推測できるが、とくに他人などを注意誹謗 することはない。自分がしたいことを自由にするのが AV であり、必要以上の干渉はほとんど無い。前述の思想信 条の共有化を信頼している面もある。何か問題が発生し た場合にはミーティングが臨機応変に開催されて協議に よって解決されている。

(4)实成長主基本的なマスタープランの方向性は あるものの、AV 住民がそれぞれ興味関心を持つことを 行っているために、新たな試みや実験が自律分散的に 行われている。生涯成長すべきという信条にも通じてお り、ゴールが決まっていないために急激な変化はなく、ゆ ๖くりと進んでいる。

(5)瑟境技術の必然性…南インドという場所は、決して環 境都市の適地ではない。しかしながら、技術発達をなし 得ていない地においては、ある面では環境技術が合理的 必然性を持ち得る。公共電力の不安定な供給は、むしろ ソーラーや風力エネルギーの個別安定供給を選択させ る、有機農業も土壌を持続的に保持するためには必要 な選択肢である。逆にゴミ処理は問題となっているが。

6)周辺村落との共生间係…周辺村落に対しては、教育 や労働の機会提供などの波及効果が大きい。AV 内が ワールドコミュニティであるため、「異文化の受容」が可能 であり、村との協調も容易になっていると思われる。

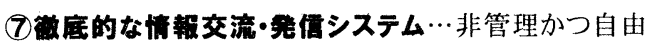
であると、誰が何をしているのかわかりにくいが、それを埋 めているのが『 Auroville News』および Solar Kitchen である。また、ゲストを積極的に迎え入れ、web や報告 書等に情報公開等による徹底的な情報発信により、理 解支援を訴えている。

\section{(2)エココミュニティ・デザインへの知見}

エココミュニティ形成において AV の実践から得られる 知見としては、そこに埋め込む社会システムとして「自由 ・信頼·実験型システム」を提案することができよう。

入出を含めた非束縛体制をとることにより、個人の意 志が尊重され、その心のゆとりから環境問題を含む社会 (コミュニティ)全体の質向上への行動を促すことができ る。アメニティの向上が結果的に社会システムの円滑化 につながるとも言える。

また、コミュニティ内の住民相互及び周辺地域とのコ ミュニケーションが非常に重要であり、顔の見える関係が 異文化・異思想のブランクを埋めることにつながり、コミュ ニティ形成を円滑に進めることになる。

生涯成長という目標が個人及び社会全体の意識の向 上につながり、環境という不可避の社会問題解決を自主 的に促すことになる。また、試行錯誤という実験体制も成 功意欲を生み、意識向上・行動に大きな影響を与えるこ とになる。

環境配慮型のコミュニティを目指すときには、資源利 用あるいはライフスタイルの点から、どうしても「管理・規 
制型システム」を志向しがちである。規制型を否定する わけではないが、AV で「そのようなこと(規制)をしたら 誰もいなくなってしまう」という意見も聞いたように、息苦 しいシステムではなく、自主的に選び取って共有化する ようなシステムは参考になる。確かに、資源が有限の中 では AVでも宅地問題などでトラブルが生じたりするが、 それも完全排除するのではなく、協議を重ねながらゆっく りと解決に向かおうとしている。そのような、自律性を尊 重しながら共生(棲)していくような作法が、30 年も持続 している鍵であると思われる。

\section{(3)今後の課題}

AVの分析はまだまだ詳細に検討すべき項目は多々あ る。個人のライフスタイルやコミュニティの組織システム などを次のステップとして考えている。また、AV創設期に おけるSri.Aurobindo, Motherの哲学の重要性について は原則的には把握できたが、その思想体系をまだ把握 しきれていない。今後その哲学体系が環境実験都市と してのAVに与えた影響の具体的解明も必要である。

謝辞:現地調査で大変お世話になつたMichiko氏、Ananda 氏、Donald氏、Marieange氏、またAuroville Newsの整理等 で協力いただいたSundar氏、Thambidurai氏、その仙街頭や 食事場等で様々なヒアリングを受けてくださった方々有り難うご ざいました。なお、本研究は、1988年度昭和シエル石油環境研 究助成「環境実験都市における環境社会システムの成立と発 展に関する研究:オーロヴィル (India)における自然循環型社 会システムへの取り組み(代表:近藤隆二郎)」の一睘として行 ったものです。記して謝意を表します。

\section{註および引用文献}

1) 土木学会睘境システム委員会編: 環境システム, pp12-14, 1998

2) 今井紀彰,オーロヴィラ(夜明けの町), ビオシティ第 5 号, pp65-72, 1994

3)目次をデータ化したもの:【 AV Notes 】 No.1(75.12) $-65+111-132+146-163(82.2):[$ AV New 】 No.1(83.5)-19 $(83.10)+21(83.10)-30(84.1)+32(84.1)-82(85.2)+84(85.3)$
$-103(85.7)+105(85.8)-190(87.5)+192(87.6)-545(94.7)+805$ (99.9) $-830(00.3)$

4)目次をデータ化したもの:[ Auroville Today ] No.1(88.11) -119(98.12)

5) Sri.Aurobindo: The Life Divine, p.40, 1950

6) 84 人への意識調査は、街頭でランダムにインタビューを実

施。属性は、(1)男 42, 女 42,(2) Indian31, foreigner53, (3) 10 代 14,20 代 17,30 代 20,40 代 18,50 代 13,60 代 2 。

\section{基礔的情報入手に使用した参考文献}

1) Mother: ON EDUCATION, 1952

2) Lan\&Tim( Auroville Communication Center) :The Auroville Handbook, 1998

3) The Auroville Today editorial team: The Auroville Adventure, 1998

4) Auroville Project Coordination Group: The City The Earth Needs, 1998

5) Auroville Project Coordination Group: A City Which Cares For Its Bioregion, 1998

6) Auroville Project Coordination Group: Healing The Earth, 1998

7) Auroville Development Group: Auroville Development Perspective 1993-1998, 1998

8) A UNIT Of The Center For Scientific Research( CSR): Auroville Building Cente, 1998

9) A UNIT Of The Center For Scientific Research( CSR): Renewable Energy, 1998

\section{キーパーソン・インタビュー調査の概要}

1)CSRのalternative energy teamチームリーダー:Hement氏 、alternative energyについて(CSR事務所991012実施)

2) Water Service Groupの Water harvest project teamチーム リーダー:Tom氏へWater harvestingについて(Water Service Group事務所991021実施)

3) CSRのWater processing teamチームリーダー:Tency 氏へ Water processingについて(CSR事務所内991013実施)

4) Auroville Greenwork Resource Centerリーダー:Yaap氏へ afforestationについて(Yaap氏宅99102実施)

5)Farm Group副リーダー:Isha氏へAVの農業について(Solar Kitchen上のカフエテリア99925実施)

6) 植林や有機農業に取り組むグループPalmyraリーダー :Jurgen氏へのAVの睘境問題について（Palmyra事務所 99115 実施)

\title{
CHARACTERIZATION OF ECO-SOCIAL SYSTEMS IN AUROVILLE WITH FOCUSING ON EXPERIMENTAL COMMUNITY ON ENVIRONMENT
}

\author{
Daisuke KATO, Ryujiro KONDO
}

\begin{abstract}
Auroville was originally started in accordance with the views of Indian philosopher 'Sri.Aurobindo' and his pupil 'Mother' in 1968. Since then, Auroville was advanced as world community under the support and protection of Indian Government and UNESCO. Auroville was established with afforestation and the solution of the conflict for village around Auroville and ashram. Now Auroville is special community, because Auroville is run without rules and leaders. We paied attention to 'Auroville's special environmental social system'. And we aimed to clarify 'Auroville's environmental social system and the factor of the foundation and advance of Auroville.' And we proposed new knowledge the way of design of the eco-community.
\end{abstract}

